\title{
HUBUNGAN STATUS GIZI DENGAN KEJADIAN ANEMIA PADA REMAJA PUTRI
}

\author{
Dea Indartanti, Apoina Kartini*) \\ Program Studi Ilmu Gizi Fakultas Kedokteran Universitas Diponegoro \\ Jl.Dr.Sutomo No.18, Semarang, Telp (024) 8453708, Email : gizifk@ undip.ac.id
}

\begin{abstract}
ABSTRAK
Latar Belakang : Masalah gizi yang biasa dialami remaja salah satunya adalah anemia. Anemia adalah keadaan dimana kadar hemoglobin $(\mathrm{Hb})$ lebih rendah dari nilai normal, yang ditandai dengan lesu, pusing, mata berkunang-kunang, dan wajah pucat, sehingga dapat menyebabkan menurunnya aktivitas dan prestasi belajar karena kurangnya konsentrasi.

Metode : Penelitian dilakukan di SMP Negeri 9 Semarang dengan desain penelitian cross-sectional. Subjek 90 remaja putri yang dipilih secara consecutive sampling. Kadar hemoglobin diukur menggunakan metode Cyanmethemoglobin, pengukuran berat badan dengan menggunakan timbangan injak digital dan tinggi badan menggunakan microtoise. Asupan protein, zat besi, vitamin C, vitamin B12 dan folat sebagai variabel perancu diperoleh dengan metode Semi Food Frequency Questionnaire (FFQ) kemudian dihitung dengan nutrisoft. Analisis bivariat menggunakan uji Chi Square kemudian dilanjutkan analisis multivariat dengan uji regresi logistik.

Hasil : Hasil penelitian diperoleh 1,1\% subyek memiliki status gizi sangat kurus, 3,3\% kurus, 73,3\% normal, 15,6\% overweight, 6,7\% obesitas dan sebanyak 26,7\% mengalami anemia. Rerata kadar hemoglobin 12,6 $\pm 1,29$ SD dan rerata nilai z-score berdasarkan IMT/U adalah 0,97 $\pm 1,18$ SD. Dilihat dari asupan diketahui bahwa sebanyak 63,3\% siswi yang asupan zat besinya kurang dari kebutuhan, sedangkan asupan protein, vitamin C, vitamin B12 dan folat sebagian besar sudah dalam kategori cukup. Hasil analisis bivariat menunjukkan tidak ada hubungan bermakna antara status gizi dengan kejadian anemia pada remaja putri $(p=0,289)$. Ada hubungan asupan zat besi $(p=0,000)$ dan asupan folat $(p=0,006)$ dengan kejadian anemia. Hasil analisis multivariat menggunakan uji regresi logistik menunjukkan variabel asupan zat besi yang berpengaruh terhadap anemia $(p<0,05)$.
\end{abstract}

Simpulan : Tidak ada hubungan antara status gizi dengan kejadian anemia pada remaja putri.

Kata Kunci : anemia; remaja; status gizi; asupan zat gizi

\begin{abstract}
Background: anemia is one of nutritional problems commonly experienced in adolescent. Anemia is a condition which the level of hemoglobin $(\mathrm{Hb})$ is lower than the normal value, and the most common symptoms is weakness, fatigue, lack of energy, dizziness, and a pale face. anemia can lead to decreased activity and school performance because of a lack of concentration.

Methods : This study used cross-sectional design with 90 adolescent girls at junior high school in semarang as subjects which were selected by consecutive sampling. Hemoglobin levels were measured using the Cyanmethemoglobin method, weight measured using digital scales and height using microtoise. Protein, iron, vitamin C, vitamin B12 and folat were obtained by Semi Food Frequency Questionnaire (FFQ) method and calculated by nutrisoft. Chi Square test was used for bivariate analysis and regression logistic test for multivariate analysis.

Result: The result showed that 1,1\% subjek were severely wasting, 3,3\% wasting, 73,3\% normal, 15,6\% overweight, $6,7 \%$ obese and $26.7 \%$ were anemia. The mean hemoglobin level of 12,6 $\pm 1,29$ SD and the mean value of the zscore based on $B M I / A$ is $0,97 \pm 1,18 S D$. The intake of iron $63,3 \%$ is low, while the intake of protein, vitamin $C$, vitamin $B 12$ and folate in enough categories. The results of the bivariate analysis showed no significant relationship between nutritional status with anemia in adolescent girls $(p=0,289)$. There is a relationship between iron intake $(p=0,000)$ and folate intake $(p=0,006)$ with anemia. Result of regression logistic test indicate that variables intake of iron related with anemia $(p<0,05)$
\end{abstract}

Conclusion: There was no significant relationship between nutritional status with the incidence of anemia on adolescent girls.

Keywords: anemia; adolescent; nutritional status; food intake

\section{PENDAHULUAN}

Remaja merupakan transisi dari masa kanak-kanak ke masa dewasa yang ditandai sejumlah perubahan biologis, kognitif, dan emosional. Perubahan biologis yaitu pertambahan tinggi badan, perubahan hormonal, dan kematangan seksual. Perubahan kognitif yang terjadi adalah meningkatnya berpikir abstrak, idealistik, dan logis. Perubahan sosio emosional meliputi tuntutan untuk mencapai kemandirian, 
konflik dengan orang tua dan keinginan untuk meluangkan waktu bersama teman sebaya. ${ }^{1}$ Oleh karena itu, masa remaja adalah masa yang lebih banyak membutuhkan zat gizi. Remaja membutuhkan asupan zat gizi yang optimal untuk pertumbuhan dan perkembangannya. ${ }^{2}$ Berdasarkan usia remaja dibagi menjadi tiga periode yaitu remaja awal pada usia 10-13 tahun, remaja pertengahan pada usia 14-16 tahun, dan remaja akhir pada usia 17-20 tahun. Puncak pertumbuhan remaja putri terjadi pada usia 12 tahun, sedangkan remaja putra terjadi pada usia 14 tahun. $^{3}$

Masalah gizi yang biasa dialami pada masa remaja salah satunya adalah anemia. Anemia adalah penurunan kuantitas sel-sel darah merah dalam sirkulasi atau jumlah hemoglobin berada dibawah batas normal. ${ }^{4}$ Gejala yang sering dialami antara lain lesu, lemah, pusing, mata berkunangkunang, dan wajah pucat. ${ }^{5}$ Anemia dapat menimbulkan berbagai dampak pada remaja antara lain menurunkan daya tahan tubuh sehingga mudah terkena penyakit, menurunnya aktivitas dan prestasi belajar karena kurangnya konsentrasi. ${ }^{6}$

Anemia defisiensi besi merupakan anemia yang paling sering terjadi pada remaja, karena kebutuhan yang tinggi untuk pertumbuhan. ${ }^{7}$ Anemia kurang zat besi lebih banyak terjadi pada remaja putri dibanding remaja putra. Data Survei Kesehatan Rumah Tangga (SKRT) tahun 2004 menyatakan bahwa prevalensi anemia gizi pada remaja putri usia (10-18 tahun) 57,1\%. Remaja putri cenderung melakukan diet sehingga dapat menyebabkan asupan zat gizi berkurang termasuk zat besi. Selain itu adanya siklus menstruasi setiap bulan merupakan salah satu faktor penyebab remaja putri mudah terkena anemia defisiensi besi. ${ }^{8}$

Anemia kurang besi dapat dipengaruhi oleh beberapa faktor yaitu, kurangnya mengkonsumsi sumber makanan hewani sebagai salah satu sumber zat besi yang mudah diserap (heme iron), sedangkan bahan makanan nabati (non-heme iron) merupakan sumber zat besi yang tinggi tetapi sulit diserap sehingga dibutuhkan porsi yang besar untuk mencukupi kebutuhan zat besi dalam seharinya. Bisa juga disebabkan karena kekurangan zat gizi yang berperan dalam penyerapan zat besi seperti, protein dan vitamin C. Konsumsi makanan tinggi serat, tannin dan phytat dapat menghambat penyerapan zat besi. ${ }^{3}$ Berbagai faktor juga dapat mempengaruhi terjadinya anemia gizi besi, antara lain pola haid, pengetahuan tentang anemia, dan status gizi. ${ }^{9}$ Anemia defisiensi vitamin B12 dan folat juga sering terjadi pada remaja karena kurangnya pemenuhan zat gizi tersebut. ${ }^{4}$

Penelitian di Sulawesi menunjukkan ada hubungan status gizi dengan kejadian anemia pada remaja putri. Hal ini dikarenakan remaja putri mempunyai kebiasaan kurang mengkonsumsi makanan sumber zat besi dan rata-rata mempunyai orang tua dengan tingkat pendidikan yang rendah sehingga pengetahuan dalam pemenuhan asupan zat gizi yang seimbang menjadi kurang. ${ }^{10}$ Berdasarkan penelitian di Meksiko diketahui bahwa defisiensi besi juga dapat terjadi 2-4 kali pada wanita dan anak-anak obesitas. Hal ini dikarenakan adanya peningkatan produksi hepcidin yang dapat menghambat penyerapan zat besi, ${ }^{11}$ sementara di Amerika Serikat (USA) menunjukkan prevalensi kekurangan zat besi lebih tinggi terjadi pada sampel remaja putra dan remaja putri yang memiliki kelebihan berat badan $(9,1 \%)$ dibanding dengan sampel yang memiliki berat badan normal $(3,1 \%){ }^{12}$

Usia 12-14 tahun termasuk dalam masa peralihan dari remaja awal ke remaja akhir yang merupakan masa pencarian identitas dan remaja cepat sekali terpengaruh oleh lingkungan. Kecemasan akan bentuk tubuh membuat remaja sengaja tidak makan atau memilih makan di luar. ${ }^{4}$ Kebiasaan ini dapat mengakibatkan remaja mengalami kerawanan pangan yang berhubungan dengan asupan zat gizi yang rendah dan berisiko pada kesehatannya termasuk anemia. Berdasarkan Riskesdas tahun 2007 prevalensi anemia remaja usia $\leq 14$ tahun di Indonesia sebanyak $12,8 \%{ }^{13}$ Berdasarkan uraian dalam latar belakang peneliti tertarik untuk meneliti hubungan status gizi dengan kejadian anemia pada remaja usia 12-14 tahun. Penelitian ini akan dilakukan di SMP Negeri 9 Semarang karena belum pernah ada penelitian seperti ini sebelumnya, sehingga bisa menjadi acuan untuk penelitian lebih lanjut mengenai anemia.

\section{METODE PENELITIAN}

Penelitian ini dilakukan pada remaja putri usia 12-14 tahun di SMP Negeri 9 Semarang pada bulan November 2013 dan termasuk lingkup gizi masyarakat dengan desain cross sectional. Jumlah sampel sebanyak 90 orang yang dipilih secara consecutive sampling dimana semua subyek yang datang dan memenuhi kriteria dimasukkan dalam penelitian. Pada penelitian ini subyek terdiri dari kelas VIII a hingga VIII h. Kriteria inklusi penelitian ini adalah siswi SMP Negeri 9 Semarang berusia 12-14 tahun yang bersedia 
menjadi subyek, tidak sedang mengkonsumsi suplemen tambah darah, tidak sedang dalam keadaan menstruasi.

Variabel dependen adalah kejadian anemia pada remaja putri. Variabel independen adalah status gizi remaja putri, sedangkan asupan protein, zat besi, vitamin $\mathrm{C}$, vitamin $\mathrm{B} 12$ dan folat merupakan variabel perancu karena merupakan faktor yang dapat mempengaruhi status gizi dan kadar hemoglobin.

Data yang dikumpulkan dalam penelitian ini adalah identitas subyek, data antropometri, kadar hemoglobin, asupan protein, asupan zat besi, vitamin B12 dan folat. Usia didapatkan dari selisih antara tahun penelitian dengan tahun kelahiran sesuai formulir yang telah diisi subyek. Berat badan dan tinggi badan didapatkan dari pengukuran langsung satu kali saat melakukan penelitian. Pengukuran berat badan dengan menggunakan timbangan injak digital kapasitas $150 \mathrm{~kg}$ dan tingkat ketelitian $0,1 \mathrm{~kg}$. Pengukuran tinggi badan menggunakan microtoise kapasitas $200 \mathrm{~cm}$ dengan ketelitian $0,1 \mathrm{~cm}$. Status gizi remaja putri ditentukan dengan menghitung nilai zscore indeks IMT/U menurut Kemenkes RI tahun 2010 yang dikategorikan menjadi sangat kurus $(<-$ $3 \mathrm{SD})$, kurus $(-3 \mathrm{SD} \mathrm{s} / \mathrm{d} \leq-2 \mathrm{SD})$, normal $(-2 \mathrm{SD} \mathrm{s} / \mathrm{d}$ 1SD) dan overweight (1SD s/d 2SD), obesitas $(\geq 2 \mathrm{SD}){ }^{14}$

Kejadian anemia pada remaja didefinisikan sebagai suatu keadaan dimana menurunnya kadar hemoglobin $(\mathrm{Hb})$ di dalam darah sehingga tidak dapat memenuhi fungsinya yang diukur menggunakan metode Cyanmethemoglobin. Pengambilan darah dilakukan oleh seorang analis dengan cara mengumpulkan siswi di aula sekolah kemudian dianalisis di salah satu Laboratorium Swasta di Semarang. Hasilnya dikategorikan menjadi anemia $(\mathrm{Hb}<12 \mathrm{mg} / \mathrm{dL})$ dan tidak anemia $(\mathrm{Hb} \geq 12 \mathrm{mg} / \mathrm{dL})$.

Asupan protein, zat besi, vitamin B12 dan folat bersumber dari makanan yang diukur dengan metode Semi Quantitative Food Frequency dalam rentang waktu 1 bulan, kemudian dihitung menggunakan nutrisoft. Asupan zat besi (Fe), vitamin $\mathrm{C}$, vitamin $\mathrm{B} 12$ dan folat kemudian dibandingkan dengan AKG remaja usia 12-14 tahun.

Data yang diperoleh kemudian dianalisis menggunakan program komputer. Analisis univariat dilakukan untuk mengidentifikasi usia subyek, berat badan, tinggi badan, nilai $\mathrm{z}$ score berdasarkan IMT/U, kadar hemoglobin, asupan protein, zat besi, vitamin C, vitamin B12 dan folat. Analisis bivariat dengan uji Chi Square untuk mengetahui hubungan status gizi dengan kejadian anemia pada remaja putri usia 12-14 tahun kemudian dilanjutkan analisis multivariat dengan uji regresi logistik.

\section{HASIL PENELITIAN}

Karakteristik subyek

Jumlah subyek sebanyak 90 orang dan didapatkan usia paling banyak 13 tahun $(83,3 \%)$. Usia minimum adalah 12 tahun dan usia maksimum 14 tahun. Rerata nilai z-score yang diperoleh berdasarkan IMT/U adalah $0,97 \pm 1,18$ $\mathrm{SD}$, nilai terendah $-3,03$ dan tertinggi 2,64. Berdasarkan nilai $z$-score menunjukkan status gizi subyek dengan kategori sangat kurus sebanyak 1 orang $(1,1 \%)$, kurus 3 orang $(3,3 \%)$, normal 66 orang $(73,3 \%)$, overweight 14 orang $(15,6 \%)$ dan obesitas 6 orang $(6,7 \%)$. Dilihat dari kadar hemoglobin menunjukan bahwa kadar hemoglobin terendah $9,9 \mathrm{gram} / \mathrm{dL}$ dan tertinggi $14,9 \mathrm{gram} / \mathrm{dL}$ serta reratanya $12,6 \pm 1,29 \mathrm{SD}$ dan sebanyak 24 orang $(26,7 \%)$ mengalami anemia. Hasil perhitungan asupan protein, zat besi, vitamin $\mathrm{C}$, vitamin B12 dan folat diketahui bahwa sebanyak $63,3 \%$ siswi yang asupan zat besinya kurang dari kebutuhan, sedangkan asupan protein, vitamin $\mathrm{C}$, vitamin B12 dan folat sebagian besar sudah dalam kategori cukup. Berikut adalah tabel karekteristik subyek.

Tabel 1. Tabel karakteristik subyek

\begin{tabular}{cc}
\hline & $\mathbf{n}(\%)$ \\
\hline Usia siswi & \\
$-\quad 12$ tahun & $10(11,1 \%)$ \\
$-\quad 13$ tahun & $75(83,3 \%)$ \\
$-\quad 14$ tahun & $5(5,6 \%)$ \\
\hline Status gizi & \\
$-\quad$ Sangat kurus & $1(1,1 \%)$ \\
$-\quad$ kurus & $3(3,3 \%)$ \\
$-\quad$ normal & $66(73,3 \%)$ \\
\hline
\end{tabular}




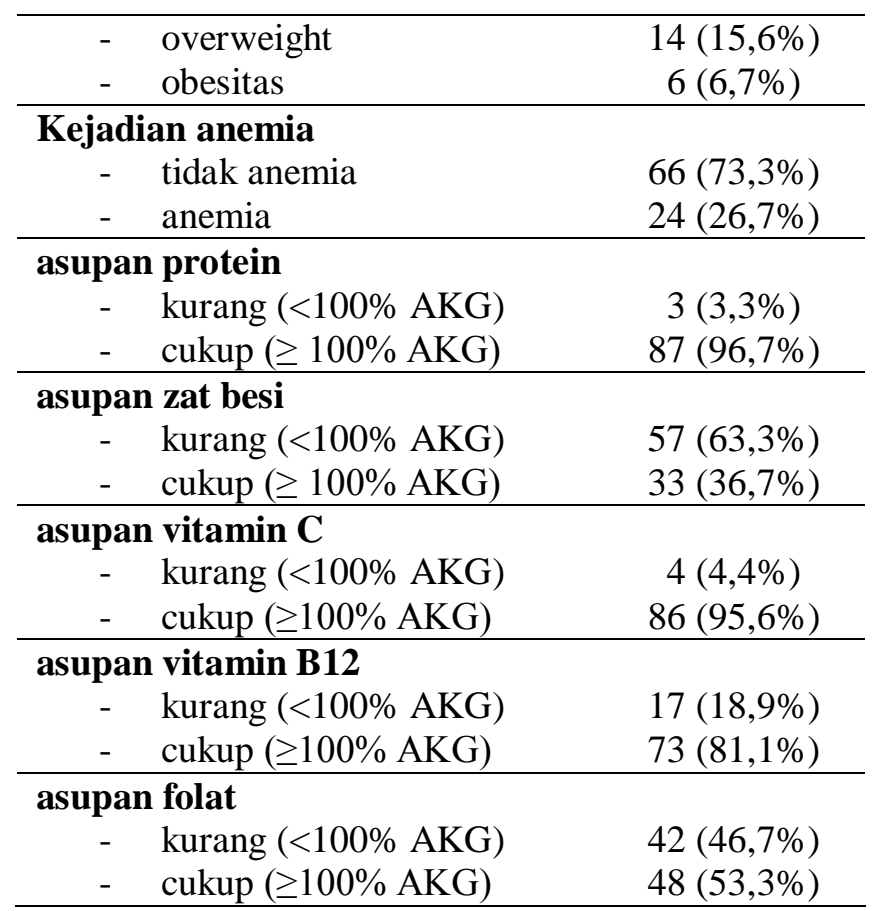

Hubungan status gizi dengan kejadian anemia Jumlah subyek yang kurus dan menderita anemia sebanyak 1 orang (25\%) sedangkan subyek yang obesitas dan menderita anemia sebanyak 3 orang (50\%). Dari analisis menggunakan uji Chi
Square diperoleh nilai $\mathrm{p}>0,05$ sehingga dapat disimpulkan bahwa tidak ada hubungan bermakna antara status gizi dengan kejadian anemia pada remaja putri. Tabel silang ditampilkan melalui tabel 5 .

Tabel 5. Tabel silang status gizi dengan status anemia subyek

\begin{tabular}{llcccc}
\hline & & \multicolumn{2}{c}{ Kejadian anemia } & Total & p value \\
\cline { 3 - 4 } & & $\begin{array}{c}\text { Tidak } \\
\text { anemia }\end{array}$ & Anemia & & \\
\cline { 3 - 4 } & & $\mathbf{n}(\%)$ & $\mathbf{n}(\%)$ & & \\
\hline Status gizi & Kurus & $3(75 \%)$ & $1(25 \%)$ & $4(100 \%)$ & 0,289 \\
& Normal & $47(71,2 \%)$ & $19(28,8 \%)$ & $66(100 \%)$ & \\
& Overweigh & $13(92,8 \%)$ & $1(7,2 \%)$ & 14 & \\
& $\mathbf{t}$ & $3(50 \%)$ & $3(50 \%)$ & $(100 \%)$ & \\
& Obesitas & & & $6(100 \%)$ & $\mathbf{9 0}$ \\
\hline Total & & & & $\mathbf{( 1 0 0 \% )}$ & \\
& & & & & \\
\hline
\end{tabular}

Hubungan asupan zat gizi dengan anemia

Hasil uji hubungan antara asupan protein, zat besi, vitamin C, vitamin B12 dan folat dengan anemia siswi diketahui asupan zat besi dan folat yang paling memiliki hubungan bermakna karena nilai $\mathrm{p}<0,05$. Berikut adalah tabel silang hubungan asupan zat gizi dengan status gizi. 
Tabel 7. Tabel silang asupan zat gizi dengan anemia

\begin{tabular}{|c|c|c|c|c|c|c|}
\hline & & \multicolumn{2}{|c|}{ status anemia } & \multirow[t]{3}{*}{ Total } & \multirow{3}{*}{$\mathbf{n}$} & \multirow{3}{*}{$\begin{array}{c}p \\
\text { value }\end{array}$} \\
\hline & & $\begin{array}{c}\text { tidak } \\
\text { anemia }\end{array}$ & anemia & & & \\
\hline & & $\mathbf{n}(\%)$ & $\mathrm{n}(\%)$ & & & \\
\hline \multirow{2}{*}{$\begin{array}{l}\text { asupan } \\
\text { protein }\end{array}$} & Kurang & $1(33,3 \%)$ & $2(66,7 \%)$ & $3(100 \%)$ & 90 & 0,111 \\
\hline & Cukup & $65(74,7 \%)$ & $22(25,3 \%)$ & $87(100 \%)$ & & \\
\hline \multirow{2}{*}{$\begin{array}{l}\text { asupan zat } \\
\text { besi }\end{array}$} & Kurang & $34(59,6 \%)$ & $23(40,4 \%)$ & $57(100 \%)$ & 90 & 0,000 \\
\hline & Cukup & $32(97 \%)$ & $1(30 \%)$ & $33(100 \%)$ & & \\
\hline \multirow{2}{*}{$\begin{array}{l}\text { asupan } \\
\text { vitamin } C\end{array}$} & Kurang & $3(75 \%)$ & $1(25 \%)$ & $4(100 \%)$ & 90 & 0,939 \\
\hline & Cukup & $63(73,3 \%)$ & $23(26,7 \%)$ & $86(100 \%)$ & & \\
\hline \multirow{2}{*}{$\begin{array}{l}\text { asupan } \\
\text { vitaminB1 } \\
2\end{array}$} & Kurang & $10(58,8 \%)$ & $7(41,2 \%)$ & $17(100 \%)$ & 90 & 0,133 \\
\hline & Cukup & $56(76,7 \%)$ & $17(23,3 \%)$ & $73(100 \%)$ & & \\
\hline \multirow{2}{*}{$\begin{array}{l}\text { asupan } \\
\text { folat }\end{array}$} & Kurang & $25(59,5 \%)$ & $17(40,5 \%)$ & $42(100 \%)$ & 90 & 0,006 \\
\hline & Cukup & $41(85,4 \%)$ & $7(14,6 \%)$ & $48(100 \%)$ & & \\
\hline
\end{tabular}

Hubungan status gizi dengan anemia setelah dikontrol dengan asupan

Hasil uji regresi logistik terhadap variabel asupan zat gizi signifikan berpengaruh terhadap kejadian anemia adalah asupan zat besi dengan nilai $p<0,05$. Berikut adalah tabel hasil uji regresi logistik variabel yang mempengaruhi anemia.

Tabel 8. Tabel analisis multivariat regresi logistik

\begin{tabular}{llll}
\hline \multicolumn{1}{c}{ variabel } & koefisien & \multicolumn{1}{c}{$\boldsymbol{p}$ value } & \multicolumn{1}{c}{ OR (IK 95\%) } \\
\hline asupan protein & 1,168 & 0,366 & $3,217(0,256-40,48)$ \\
asupan zat besi & 2,789 & 0,011 & $16,259(1,912-$ \\
& & & $138,29)$ \\
asupan vitamin B12 & 0,473 & 0,458 & $1,605(0,460-5,60)$ \\
asupan folat & 0,345 & 0,615 & $1,357(0,413-4,45)$ \\
\hline
\end{tabular}

\section{PEMBAHASAN}

Status gizi merupakan keadaan tubuh sebagai akibat antara konsumsi, penyerapan dan penggunaan zat-zat gizi atau keadaan fisiologik akibat dari tersedianya zat gizi dalam tubuh. ${ }^{15} \mathrm{Pada}$ penelitian ini sebagian besar subyek memiliki status gizi sangat kurus 1 orang $(1,1 \%)$, kurus 3 orang $(3,3 \%)$, normal 66 orang $(73,3 \%)$, overweight 14 orang $(15,6 \%)$, dan obesitas sebanyak 6 orang $(6,7 \%)$. Beberapa faktor yang memicu terjadinya masalah gizi pada usia remaja seperti kebiasaan makan yang salah, pemahaman gizi yang keliru dimana tubuh yang langsing menjadi idaman para remaja sehingga kebutuhan gizi tidak terpenuhi, dan kesukaan yang berlebihan terhadap makanan tertentu contohnya makanan cepat saji (fast food). ${ }^{16}$

Berdasarkan hasil uji statistik menunjukkan tidak ada hubungan bermakna antara status gizi dengan kejadian anemia ( $p>0,05)$. Hal ini dikarenakan sebagian besar subyek tergolong dalam status gizi normal. Status gizi berdasarkan indikator IMT/U lebih dipengaruhi asupan zat gizi makro (karbohidrat, lemak, protein). ${ }^{17}$ Karbohidrat, lemak dan protein merupakan zat gizi penyuplai energi terbesar bagi tubuh. ${ }^{18}$ Asupan energi kurang dari kebutuhan dalam jangka waktu tertentu akan menyebabkan terjadi penurunan status gizi, bila asupan energi seimbang akan membantu memelihara status gizi normal dan jika asupan energi berlebihan atau berkurangnya pengeluaran energi berpotensi terjadinya kegemukan. ${ }^{19}$ Asupan zat gizi mikro tidak mempengaruhi status gizi berdasarkan IMT/U karena memiliki kandungan energi yang sedikit, dan jika terjadi kekurangan mungkin sudah berlangsung lama. $^{20}$ Pada penelitian ini asupan zat gizi mikro subyek seperti 
vitamin $\mathrm{C}$, vitamin B12 dan folat sudah tergolong cukup baik.

Hasil ini bertentangan dengan penelitian di Poliwali Mandar yang menyatakan ada hubungan status gizi dengan kejadian anemia pada remaja putri. Semakin tinggi remaja yang memiliki status gizi kurang maka semakin tinggi angka kejadian anemia pada remaja putri. ${ }^{10}$ Status gizi pada remaja di Indonesia meliputi kurang zat gizi makro (karbohodrat, protein, lemak) dan kurang gizi mikro (vitamin dan mineral). Apabila status gizi tidak normal maka dikhawatirkan status zat besi juga tidak baik, sehingga dapat menyebabkan anemia. $^{21}$

Anemia adalah menurunnya jumlah hemoglobin dari batas normal sehingga tidak dapat memenuhi fungsinya untuk membawa oksigen dalam jumlah yang cukup ke jaringan perifer. Nilai batas normal kadar hemoglobin untuk remaja putri adalah < 12 gram/dL. ${ }^{5}$ Jumlah siswi yang mengalami anemia sebanyak 24 orang $(26,7 \%)$. Anemia dapat disebabkan oleh karena gangguan pembentukan eritrosit oleh sumsum tulang, kehilangan darah keluar dari tubuh (perdarahan), proses penghancuran eritrosit dalam tubuh sebelum waktunya (hemolisis), kurangnya asupan zat besi, vitamin C, vitamin B12 dan folat. ${ }^{7}$ Dari hasil uji regresi logistik diketahui ada hubungan asupan zat besi dengan anemia. Dilihat dari asupan zat besi sebanyak $63,3 \%$ subyek termasuk dalam kategori kurang dari kebutuhan yaitu $20 \mathrm{mg}$ untuk usia 1012 tahun dan $26 \mathrm{mg}$ untuk usia 13-15 tahun, ${ }^{23}$ karena siswi mempunyai kebiasaan kurang mengkonsumsi makanan sumber zat besi yang mudah diserap (heme iron) seperti daging, ikan, dan unggas. Siswi lebih banyak mengkonsumsi makanan sumber zat besi non heme seperti tahu, tempe dan kacang-kacangan.

Zat besi adalah komponen penting hemoglobin. Hemoglobin mengandung besi yang disebut hem dan protein globulin. Setiap molekul hemoglobin mengikat oksigen untuk diedarkan ke seluruh tubuh. ${ }^{4}$ Pada remaja putri, kebutuhan yang tinggi akan besi terutama disebabkan kehilangan zat besi selama menstruasi. ${ }^{16}$ Beberapa faktor penyebab kurangnya konsumsi zat besi pada remaja adalah ketersediaan pangan, kurangnya pengetahuan dan kebiasaan makan yang salah. ${ }^{22}$

Asupan protein subyek tergolong dalam kategori cukup. Asupan protein sebanyak 96,7\% subyek mengkonsumsi $\geq 50$ gram untuk usia 10-12 tahun dan $\geq 57$ gram untuk usia 13-15 tahun. ${ }^{23}$ Protein berperan penting dalam transportasi zat besi dalam tubuh. Kurangnya asupan protein akan mengakibatkan transportasi zat besi terhambat sehingga akan terjadi defisiensi besi. Absorpsi besi yang terjadi di usus halus dibantu oleh alat angkut protein yaitu transferin dan feritin. Transferin mengandung besi berbentuk ferro yang berfungsi mentranspor besi ke sumsum tulang untuk pembentukkan hemoglobin. ${ }^{24}$

Asupan vitamin C, vitamin B12 dan folat subyek juga tergolong cukup. Asupan vitamin $\mathrm{C}$ sebanyak $95,6 \%$ subyek mengkonsumsi $\geq 50 \mathrm{mg}$ usia 10-12 tahun dan $\geq 65 \mathrm{mg}$ usia 13-15 tahun. ${ }^{23}$ Sumber vitamin $\mathrm{C}$ yang banyak dikonsumsi siswi seperti jeruk, apel, mangga, pisang. Vitamin $\mathrm{C}$ berfungsi mempercepat penyerapan zat besi. ${ }^{24}$ Asupan vitamin B12 sebanyak $81,1 \%$ subyek mengkonsumsi $\geq 1,8 \mu \mathrm{g}$ untuk usia 10-12 tahun dan $\geq 2,4 \mu \mathrm{g}$ untuk usia $13-15$ tahun. ${ }^{23}$ Sumber vitamin B12 yang banyak dikonsumsi subyek adalah telur dan susu. Asupan folat sebanyak 53,3\% subyek mengkonsumsi $\geq 300 \mu \mathrm{g}$ untuk usia 10-12 tahun dan $\geq 400 \mu \mathrm{g} .{ }^{23}$ Sumber folat yang banyak dikonsumsi subyek seperti sayur bayam, hati, buah, kacang termasuk dalam kategori cukup. Vitamin B12 dan asam folat penting untuk sintesis DNA. Apabila kekurangan salah satu diantaranya dapat mempengaruhi regenerasi seluler dan menyebabkan terjadinya anemia makrositik, dimana ukuran sel-sel darah merah lebih besar dari normal. ${ }^{4}$

\section{KETERBATASAN PENELITIAN}

Keterbatasan dalam penelitian ini yaitu tidak dapat menjangkau semua kelas di SMP Negeri 9 Semarang tetapi hanya diwakili kelas VIII a sampai VIII h yang terpilih oleh peneliti dikarenakan ijin yang diberikan oleh guru. Hanya melakukan pemeriksaan kadar hemoglobin, tidak melakukan pemeriksaan darah lebih lanjut untuk memastikan terjadinya anemia defisiensi besi misalnya kadar ferritin.

\section{SIMPULAN}

Sebagian besar siswi termasuk dalam status gizi normal yaitu sebanyak 66 orang $(73,3 \%)$, tetapi ada 1 orang siswi $(1,1 \%)$ yang masuk dalam kategori sangat kurus, 3 orang $(3,3 \%)$ kurus, 14 orang $(15,6 \%)$ overweight dan 6 orang obesitas $(6,7 \%)$. Jumlah siswi yang mengalami anemia sebanyak 24 orang $(26,7 \%)$. Tidak ada hubungan bermakna antara status gizi dengan kejadian anemia pada remaja putri. Dilihat dari asupan diketahui sebagian besar siswi sudah dalam kategori cukup, tetapi terdapat $63,3 \%$ siswi yang asupan zat besinya kurang dari kebutuhan. 
Dari hasil uji regresi logistik diketahui ada hubungan asupan zat besi dengan kejadian anemia.

\section{SARAN}

Remaja putri perlu meningkatkan konsumsi zat besi terutama saat menstruasi. Bagi remaja putri yang memiliki status gizi kurus dan overweight perlu menjaga status gizinya menjadi normal dengan mencukupi asupan zat gizi baik kuantitas maupun kualitasnya

\section{DAFTAR PUSTAKA}

1. Santrock, John W. Adolescence, eleventh edition. Jakarta: Erlangga. 2007.

2. Soetjiningsih. Tumbuh Kembang Remaja dan Permasalahannya. Jakarta: Sagung Seto. 2004.

3. Nelson. Ilmu Kesehatan Anak volume 1. (diterjemahkan oleh: Samik Wahab). Jakarta: EGC. 1996.

4. Corwin, Elizabeth J. Handbook of Pathophysiologi, 3rd Ed. Jakarta: EGC. 2009.

5. American Society of Hematology. Anemia. 2013. Avalaible from: http:www.hematology.org

6. Michael J, Gibney, Barrie M. Public Health Nutrition. (diterjemahkan oleh: Andry Hartono). Jakarta: EGC. 2005.

7. Sudoyo Aru W, Bambang Setiyohadi, Idrus Alwi. Ilmu Penyakit Dalam. Jakarta: Fakultas Kedokteran Universitas Indonesia. 2006.

8. Heather A Eicher-Miller, April C Mason, Connie M Weave. Food insecurity is associated with iron deficiency anemia in US Adolescents. Am J Clin Nutr. 2009. 90:135871.

9. Adriyana. Faktor-Faktor yang Berhubungan dengan Kejadian Anemia Remaja Putri di Madrasah Aliyah Negeri 2 Bogor. Skripsi: Fakultas Kedokteran dan Ilmu Kesehatan Universitas Islam Negri Syarif Hidayatullah Jakarta. 2010.

10. Hapzah. Hubungan Tingkat Pengetahuan dan Status Gizi Terhadap Kejadian Anemia Remaja Putri Pada Siswi Kelas III di SMAN 1 Tinambung Kabupaten Polewali Mandar. Skripsi: STIKES Bina Bangsa Majene Sulawesi Barat. 2012.

11. Ana C Cepeda-Lopez et al. Sharply higher rates of iron deficiency in obese Mexican women and children are predicted by obesityrelated inflammation rather than by differences in dietary iron intake. Am J Clin Nutr 2011;93:975-83.

12. J, Nead Karen et al. Overweight Children and Adolescence: A Risk Group For Iron Deficiency. 2004. Avalaible from: http:www.pediatric.com.
13. Riset Kesehatan Dasar. Jakarta : Badan Penelitian Kesehatan Kementrian Kesehatan RI. 2007.

14. Kemenkes RI. Keputusan Menteri Kesehatan Republik Indonesia NO. 1995/Menkes/SK/XII/2010 tentang Standar Antropometri Penilaian Status Gizi Anak. 2010.

15. Supariasa. Penilaian Status Gizi. Jakarta: EGC. 2002.

16. Nurhaedar Jafar. Perilaku Gizi Seimbang Pada Remaja. Skripsi: Fakultas Kesehatan Masyarakat Universitas Hasanuddin. 2012.

17. Muchlisa. Hubungan Asupan Zat Gizi dengan Status Gizi Pada Remaja Putri di Fakultas Kesehatan Masyarakat Universitas Hasanuddin Makasar. Skripsi: Fakultas Kesehatan Masyarakat Universitas Hasanuddin. 2013.

18. Arisman. Gizi dalam Daur Kehidupan. Jakarta: Penerbit Buku Kedokteran EGC. 2009.

19. Moehji, S. Penanggulangan Gizi Buruk. Jakarta: Papar Sinar Sinanti. 2003.

20. Yuniar Rosmalina, Fitrah Ernawati. Hubungan Status Zat Gizi Mikro dengan Status Gizi Pada Anak Remaja SLTP. Puslitbang Gizi dan Makanan, Badan Litbangkes. 2010.

21. Anie Kurniawan. Remaja Putri di Kab. Tangerang Menderita Anemia. 2005. Available from:http://www.gizi.net.com.

22. Dewi Permaesih. Faktor-faktor yang Mempengaruhi Anemia Pada Remaja. Puslitbang Gizi dan Makanan, Badan Litbangkes. 2005.

23. Tabel Angka Kebutuhan Gizi bagi Orang Indonesia. 2004.

24. Webb, Geoffrey P. Dietary Supplements and Functional Foods. UK: Blackwell Publishing Ltd. 2006. 